\title{
Distribution of Hospital Provision: Policy Themes and Resource Variations
}

\author{
M. J. BUXTON, R. E. KLEIN
}

British Medical fournal, 1975, 1, 345-347

\section{Summary}

There has been much discussion in the past about the inequitable distribution of N.H.S. resources between different regions. This paper examines the distribution of hospital resources in terms of current revenue and beds in different specialties in eight regions (49 area health authorities). Variations between A.H.A.s are far more important than those between regions, and indeed they are so large (even in the acute specialties) that it is doubtful whether some A.H.A.s can be considered to be offering a comprehensive service. In the light of these findings the paper explores policy problems involved in trying to secure a more equitable distribution of N.H.S. resources at a time of financial stringency.

\section{Introduction}

The geographical maldistribution of health resources, notably doctors, nurses, and beds, is an international problem. Even leaving aside the question of matching resources to health needs - which are difficult to define with precision and more difficult still to translate into specific requirements for particular forms or levels of care-there is no health system which has yet managed to achieve even the far more crude objective of equal access to resources for the total population. There are considerable differences in the distribution of resources both in a free-market health system like the United States ${ }^{1}$ and in a planned system like Soviet Russia. ${ }^{2}$ In a mixed system, like France, the bestendowed region has almost twice as many beds as the worst-off: there are 8.3 beds per 1000 population in public and private hospitals in Alsace as against only 4.3 in the Nord. ${ }^{3}$ There are also large differences between and within the various Länder in Germany. ${ }^{4}$ When there is no rationing by price, there tends to be rationing by the geographical availability of resources.

This is the background to one of the endemic problems of the N.H.S.: that of securing a more equitable distribution of resources between different parts of the country. From the start, it has been acknowledged that the actual distribution reflects more closely the historical inheritance of the N.H.S. than present-day requirements, however these may be definedwhether in relation to population numbers and structure, or morbidity and mortality patterns. But attempts to change this situation have had only limited success. There are still large

variations in the list sizes of family practitioners in different parts of the country ${ }^{5}$; similarly there are considerable variations in the provision of community health services. ${ }^{6}$ Neither seems to be positively related to particular local health requirements.

\section{NEW FORMULA}

One of the most frequently discussed variations has been that in the resources allocated to the hospital services of the different regions, ${ }^{78}$ not surprisingly since these resources account for two-thirds of the N.H.S.'s total budget. Indeed, in 1970 the Department of Health and Social Security in effect acknowledged the need to allocate funds more rationally by introducing a formula ${ }^{9}$ - since refined but not fundamentally altered-for distributing resources to the regions. This new formula was designed to bring about a more equal distribution of resources over a 10-year period; even so, it will not remove all inequalities. ${ }^{10}$

But regional variations are of only limited significance: they have probably attracted so much attention because of the lack of information up till now about the distribution of hospital resources at the subregional level. The fact that a particular region is well or badly endowed does not necessarily tell us anything about provisions for specific communities within it. This paper, therefore, examines the distribution of hospital resources within the regions, and looks at the variations between area health authorities. It is the function of each A.H.A., in the words of the white paper ${ }^{11}$ introducing the plans for reorganization, to provide a "comprehensive health service designed to meet the needs of the communities within its districts." So it is essential to know just how well or badly placed different A.H.A.s are to carry out this comprehensive function. This sort of analysis is all the more relevant for future policy making at a time when the issue of priorities in the distribution of resources within the N.H.S. has gained added urgency because of the overall scarcity of funds.

\section{Data and Their Limitations}

To obtain data about the distribution of resources by A.H.A.s, we drew on the area profiles that were prepared by the shadow authorities as part of the preparations for reorganization. These were obtained either directly from the A.H.A.s or from the regions, and we have collected information about 49 areas in eight out of the 14 English regions. The eight include two with resources, measured in terms of money spent per head of population, well above the national average (the South West Thames and Mersey, with $41 \%$ and $7 \%$ above the national average respectively), some around the national average (the South Western and Yorkshire) and some well below it (West Midland and Trent, $-15 \%$ and $-23 \%$ respectively). Throughout the figures refer to the financial year 1971-2 and include current expenditure on the hospital service only; for the sake of 
simplicity, the postreorganization names of the regions have been used.

When asking the shadow A.H.A.s to prepare profiles the D.H.S.S. gave specific guidance as to the way in which the information should be presented. ${ }^{12}$ In practice, though, some A.H.A.s seem to have ignored this guidance. This may be understandable in terms of the many competing demands on understaffed teams of officers. Furthermore in some cases the profiles had to be completed before the final boundaries of the A.H.A.s had been settled in detail. So the information in the profiles is not always presented in a consistent form, is sometimes incomplete, and occasionally not entirely accurate.

\section{RELATIVE DISTRIBUTION}

In table I we have presented the data in terms of the relationship between the level of provision in each A.H.A. and the national average. This deliberately puts the emphasis on the relative distribution of resources, as distinct from the absolute amount of money spent and beds available in any one A.H.A. For it is clear that the actual amounts are sometimes inaccurate, and in any case will have changed since 1971-2. But there is no evidence that a revision of the figures would lead to much change in the pattern of relativities as distinct from the position of any particular A.H.A. The case for publishing the data at this stage - despite their imperfections-is that they raise some basic policy issues which are unlikely to be affected by future revisions and which need debating without waiting for statistical perfection. Hopefully the D.H.S.S. will eventually publish its own figures of the distribution by A.H.A.s of resources, in all their various dimensions.

There is a further gap in the data. Administrative boundaries, as everyone knows, do not necessarily correspond to hospital catchment areas. This problem is particularly acute in conurbations like Birmingham, where the new local authority boundaries often do not match the existing patterns of health provision. Figures about resource provision, it may be argued, may give a misleading impression about the availability of health care unless they are supplemented by information about cross-

TABLE I-Distribution of Hospital Resources by Area Health Authorities for Eight Regions, 1971-2

\begin{tabular}{|c|c|c|c|c|c|c|c|c|c|c|c|c|}
\hline & \multirow[b]{3}{*}{\begin{tabular}{|} 
Population \\
(thousands)
\end{tabular}} & \multicolumn{11}{|c|}{$\%$ Variation from National Average for Provision per Capita } \\
\hline & & \multirow[b]{2}{*}{$\begin{array}{l}\text { Current } \\
\text { Expendi- } \\
\text { ture }\end{array}$} & \multirow[b]{2}{*}{ Total } & \multirow[b]{2}{*}{$\begin{array}{l}\text { General } \\
\text { Medicine }\end{array}$} & \multicolumn{5}{|c|}{ BEDS } & \multirow[b]{2}{*}{$\begin{array}{c}\text { Maternity } \\
\text { (Adjusted) } \dagger\end{array}$} & \multirow[b]{2}{*}{$\begin{array}{l}\text { Geriatric } \\
\text { and } \\
\text { Chronic } \\
\text { Sick }\end{array}$} & \multirow[b]{2}{*}{$\begin{array}{c}\text { Geriatric } \\
\text { and } \\
\text { Chronic Sick } \\
\text { (Adjusted) } \ddagger\end{array}$} \\
\hline & & & & & $\begin{array}{l}\text { General } \\
\text { Surgery }\end{array}$ & $\begin{array}{l}\text { Traumatic } \\
\text { and } \\
\text { Orthopaedic } \\
\text { Surgery }\end{array}$ & $\begin{array}{l}\text { Mental } \\
\text { Handicap }\end{array}$ & $\begin{array}{l}\text { Mental } \\
\text { Illness }\end{array}$ & Maternity & & & \\
\hline $\begin{array}{l}\text { Cheshire } \\
\text { Liverpool* } \\
\text { St. Helens }\end{array}$ & $\begin{array}{l}865 \\
607 \\
377\end{array}$ & $\begin{array}{r}-11 \\
62 \\
-34\end{array}$ & $\begin{array}{l}39 \\
38 \\
13\end{array}$ & $\begin{array}{r}-25 \\
192 \\
5\end{array}$ & $\begin{array}{r}0 \\
130 \\
-25\end{array}$ & $\begin{array}{r}\text { Mersey } \\
-28 \\
90 \\
-12\end{array}$ & $\begin{array}{r}77 \\
-47 \\
-100\end{array}$ & $\begin{array}{r}122 \\
-69 \\
165\end{array}$ & $\begin{array}{r}-17 \\
99 \\
-43\end{array}$ & $\begin{array}{r}-18 \\
105 \\
-44\end{array}$ & $\begin{array}{r}42 \\
31 \\
-60\end{array}$ & $\begin{array}{r}65 \\
36 \\
-55\end{array}$ \\
\hline $\begin{array}{l}\text { Sefton } \\
\text { Wirral }\end{array}$ & $\begin{array}{l}425 \\
355\end{array}$ & $\begin{array}{l}-15 \\
-10\end{array}$ & $\begin{array}{l}-6 \\
-2\end{array}$ & $\begin{array}{l}71 \\
60\end{array}$ & $\begin{array}{l}23 \\
85\end{array}$ & $\begin{array}{r}-1 \\
95\end{array}$ & $\begin{array}{r}19 \\
-86\end{array}$ & $\begin{array}{l}-90 \\
-77\end{array}$ & $\begin{array}{r}-12 \\
17\end{array}$ & $\begin{array}{r}-10 \\
21\end{array}$ & $\begin{array}{l}-18 \\
-23\end{array}$ & $\begin{array}{l}-19 \\
-40\end{array}$ \\
\hline $\begin{array}{l}\text { Berkshire } \\
\text { Buckinghamshire } \\
\text { Northamptonshire } \\
\text { Oxfordshire* }\end{array}$ & $\begin{array}{l}624 \\
477 \\
468 \\
505\end{array}$ & $\begin{array}{r}-10 \\
-29 \\
-32 \\
3\end{array}$ & $\begin{array}{r}1 \\
-24 \\
-15 \\
24\end{array}$ & $\begin{array}{l}-11 \\
-29 \\
-36 \\
-21\end{array}$ & $\begin{array}{r}1 \\
-33 \\
-9 \\
-19\end{array}$ & $\begin{array}{r}\text { Oxford } \\
7 \\
-54 \\
17 \\
60\end{array}$ & $\begin{array}{r}49 \\
-54 \\
-59 \\
71\end{array}$ & $\begin{array}{r}-37 \\
-39 \\
-24 \\
43\end{array}$ & $\begin{array}{r}27 \\
9 \\
-9 \\
6\end{array}$ & $\begin{array}{r}20 \\
5 \\
-8 \\
2\end{array}$ & $\begin{array}{r}-19 \\
-23 \\
49 \\
-19\end{array}$ & $\begin{array}{r}1 \\
-9 \\
53 \\
-5\end{array}$ \\
\hline $\begin{array}{l}\text { Avon* } \\
\text { Cornwall } \\
\text { Devon } \\
\text { Gloucestershire } \\
\text { Somerset }\end{array}$ & $\begin{array}{l}901 \\
378 \\
896 \\
467 \\
386\end{array}$ & $\begin{array}{r}14 \\
-30 \\
-14 \\
-36 \\
-17\end{array}$ & $\begin{array}{r}23 \\
-7 \\
14 \\
-18 \\
21\end{array}$ & $\begin{array}{r}33 \\
-38 \\
-32 \\
-45 \\
-44\end{array}$ & $\begin{array}{r}-7 \\
-41 \\
0 \\
-22 \\
-38\end{array}$ & \begin{tabular}{|} 
South Western \\
32 \\
-30 \\
-18 \\
5 \\
-40
\end{tabular} & $\begin{array}{r}190 \\
-39 \\
46 \\
-100 \\
29\end{array}$ & $\begin{array}{r}-42 \\
31 \\
18 \\
4 \\
77\end{array}$ & $\begin{array}{r}36 \\
-5 \\
6 \\
18 \\
17\end{array}$ & $\begin{array}{r}37 \\
4 \\
18 \\
21 \\
26\end{array}$ & $\begin{array}{l}-5 \\
24 \\
24 \\
10 \\
66\end{array}$ & $\begin{array}{r}-9 \\
-6 \\
-11 \\
9 \\
40\end{array}$ \\
\hline $\begin{array}{l}\text { Croydon } \\
\text { Kingston and } \\
\text { Richmond }\end{array}$ & $\begin{array}{l}334 \\
250\end{array}$ & $\begin{array}{l}\text { N.A. } \\
\text { N.A. }\end{array}$ & $\begin{array}{l}35 \\
30\end{array}$ & $\begin{array}{l}\text { N.A. } \\
\text { N.A. }\end{array}$ & $\begin{array}{l}\text { N.A. } \\
\text { N.A. }\end{array}$ & $\begin{array}{l}\text { uth West Thame } \\
\text { N.A. } \\
\text { N.A. }\end{array}$ & $\begin{array}{r}331 \\
-13 \\
\end{array}$ & $\begin{array}{r}4 \\
170\end{array}$ & $\begin{array}{r}0 \\
-9 \\
\end{array}$ & $\begin{array}{l}\text { N.A. } \\
\text { N.A. }\end{array}$ & $\begin{array}{r}0 \\
-38\end{array}$ & $\begin{array}{r}5 \\
-44 \\
\end{array}$ \\
\hline $\begin{array}{l}\text { Merton, Sutton } \\
\text { and Wandsworth* }\end{array}$ & 680 & N.A. & 58 & N.A. & N.A. & N.A. & 40 & 105 & 26 & N.A. & 29 & 17 \\
\hline $\begin{array}{l}\text { Surrey } \\
\text { West Sussex }\end{array}$ & $\begin{array}{r}1111 \\
627\end{array}$ & $\begin{array}{l}\text { N.A. } \\
\text { N.A. }\end{array}$ & $\begin{array}{r}32 \\
-19\end{array}$ & $\begin{array}{l}\text { N.A. } \\
\text { N.A. }\end{array}$ & $\begin{array}{l}\text { N.A. } \\
\text { N.A. }\end{array}$ & $\begin{array}{l}\text { N.A. } \\
\text { N.A. }\end{array}$ & $\begin{array}{r}124 \\
-28\end{array}$ & $\begin{array}{l}86 \\
11\end{array}$ & $\begin{array}{l}\mathbf{4} \\
1\end{array}$ & $\begin{array}{l}\text { N.A. } \\
\text { N.A. }\end{array}$ & $\begin{array}{l}-23 \\
-34\end{array}$ & $\begin{array}{l}-20 \\
-56\end{array}$ \\
\hline $\begin{array}{l}\text { Barnsley } \\
\text { Derbyshire } \\
\text { Doncaster } \\
\text { Leicestershire* } \\
\text { Lincolnshire } \\
\text { Nottinghamshire* } \\
\text { Rotherham } \\
\text { Sheffield* }\end{array}$ & $\begin{array}{l}225 \\
885 \\
280 \\
798 \\
503 \\
973 \\
243 \\
572\end{array}$ & $\begin{array}{r}-51 \\
-37 \\
-18 \\
-40 \\
-14 \\
-17 \\
-62 \\
34\end{array}$ & $\begin{array}{l}-55 \\
-31 \\
-15 \\
-27 \\
16 \\
-23 \\
-60 \\
20\end{array}$ & $\begin{array}{l}-22 \\
-63 \\
-29 \\
-63 \\
-26 \\
-28 \\
-57 \\
12\end{array}$ & $\begin{array}{r}-29 \\
-45 \\
-7 \\
-31 \\
-6 \\
-10 \\
-39 \\
22\end{array}$ & $\begin{array}{r}\text { Trent } \\
-31 \\
-39 \\
-14 \\
-58 \\
-8 \\
4 \\
-65 \\
43\end{array}$ & $\begin{array}{r}-100 \\
-45 \\
69 \\
-13 \\
58 \\
-53 \\
-100 \\
19\end{array}$ & $\begin{array}{r}-88 \\
-21 \\
-64 \\
-26 \\
35 \\
-31 \\
-100 \\
-2\end{array}$ & $\begin{array}{r}-8 \\
-29 \\
56 \\
-9 \\
2 \\
-21 \\
-33 \\
32\end{array}$ & $\begin{array}{r}-7 \\
-28 \\
54 \\
-10 \\
5 \\
-21 \\
-34 \\
38\end{array}$ & $\begin{array}{r}-29 \\
-12 \\
-12 \\
-15 \\
-1 \\
-15 \\
-5 \\
34\end{array}$ & $\begin{array}{r}-20 \\
-9 \\
7 \\
-8 \\
-5 \\
-5 \\
16 \\
32\end{array}$ \\
\hline $\begin{array}{l}\text { Dorset } \\
\text { Hampshire* } \\
\text { Isle of Wight } \\
\text { Wiltshire }\end{array}$ & $\begin{array}{r}554 \\
1353 \\
110 \\
676\end{array}$ & $\begin{array}{l}-18 \\
-21 \\
-12 \\
-10\end{array}$ & $\begin{array}{r}10 \\
-4 \\
6 \\
5\end{array}$ & $\begin{array}{l}\text { N.A. } \\
\text { N.A. } \\
\text { N.A. } \\
\text { N.A. }\end{array}$ & $\begin{array}{l}\text { N.A. } \\
\text { N.A. } \\
\text { N.A. } \\
\text { N.A. }\end{array}$ & $\begin{array}{c}\text { Wessex } \\
\text { N.A. } \\
\text { N.A. } \\
\text { N.A. } \\
\text { N.A. }\end{array}$ & $\begin{array}{l}-39 \\
-13 \\
-14 \\
-26\end{array}$ & $\begin{array}{r}63 \\
46 \\
52 \\
4\end{array}$ & $\begin{array}{r}-5 \\
-15 \\
-41 \\
9\end{array}$ & $\begin{array}{r}8 \\
-17 \\
-28 \\
10\end{array}$ & $\begin{array}{r}36 \\
-25 \\
19 \\
56\end{array}$ & $\begin{array}{r}-12 \\
-22 \\
-24 \\
53\end{array}$ \\
\hline $\begin{array}{l}\text { Birmingham* } \\
\text { Coventry } \\
\text { Dudley } \\
\text { Hereford and } \\
\text { Worcester }\end{array}$ & $\begin{array}{r}1098 \\
337 \\
294 \\
559\end{array}$ & $\begin{array}{r}10 \\
-30 \\
-40 \\
-12\end{array}$ & $\begin{array}{r}4 \\
-44 \\
-40 \\
46\end{array}$ & $\begin{array}{r}2 \\
-24 \\
18 \\
-28\end{array}$ & $\begin{array}{r}8 \\
-24 \\
22 \\
-13\end{array}$ & $\begin{array}{l}\text { West Midlands } \\
\begin{array}{|c}34 \\
21 \\
-9 \\
-20\end{array}\end{array}$ & $\begin{array}{r}-28 \\
-100 \\
-56 \\
68\end{array}$ & $\begin{array}{r}0 \\
-95 \\
-86 \\
61\end{array}$ & $\begin{array}{r}14 \\
8 \\
-18 \\
-7\end{array}$ & $\begin{array}{r}20 \\
7 \\
-22 \\
-8\end{array}$ & $\begin{array}{r}20 \\
-25 \\
-33 \\
16\end{array}$ & $\begin{array}{r}25 \\
-3 \\
-19 \\
20\end{array}$ \\
\hline $\begin{array}{l}\text { Sandwell } \\
\text { Shropshire } \\
\text { Solihull } \\
\text { Staffordshire } \\
\text { Walsall } \\
\text { Warwickshire } \\
\text { Wolverhampton }\end{array}$ & $\begin{array}{l}330 \\
337 \\
192 \\
962 \\
273 \\
456 \\
268\end{array}$ & $\begin{array}{l}-69 \\
-22 \\
20 \\
\text { N.A. } \\
-50 \\
\text { N.A. } \\
\text { N.A. }\end{array}$ & $\begin{array}{r}-74 \\
-3 \\
74 \\
3 \\
-10 \\
9 \\
-37\end{array}$ & $\begin{array}{l}-57 \\
-43 \\
-2 \\
-35 \\
-45 \\
-10 \\
-38\end{array}$ & $\begin{array}{r}-51 \\
9 \\
22 \\
-28 \\
-8 \\
-6 \\
-12\end{array}$ & $\begin{array}{r}-60 \\
155 \\
-38 \\
-5 \\
-63 \\
-18 \\
-50\end{array}$ & $\begin{array}{r}-100 \\
-95 \\
292 \\
-33 \\
296 \\
133 \\
-100\end{array}$ & $\begin{array}{r}-100 \\
-3 \\
21 \\
51 \\
-100 \\
-8 \\
-78\end{array}$ & $\begin{array}{r}-49 \\
-1 \\
114 \\
-17 \\
-28 \\
-6 \\
25\end{array}$ & $\begin{array}{r}-47 \\
-1 \\
96 \\
-21 \\
-31 \\
-11 \\
\text { N.A. }\end{array}$ & $\begin{array}{r}-55 \\
51 \\
-30 \\
31 \\
-41 \\
23 \\
-32\end{array}$ & $\begin{array}{r}-49 \\
54 \\
8 \\
61 \\
-17 \\
54 \\
\text { N.A. }\end{array}$ \\
\hline $\begin{array}{l}\text { Bradford } \\
\text { Calderdale } \\
\text { Humberside } \\
\text { Kirklees } \\
\text { Leeds* } \\
\text { N. Yorkshire } \\
\text { Wakefield }\end{array}$ & $\begin{array}{l}461 \\
195 \\
838 \\
369 \\
737 \\
628 \\
302\end{array}$ & $\begin{array}{r}-13 \\
-33 \\
-25 \\
-13 \\
2 \\
-15 \\
1\end{array}$ & $\begin{array}{r}10 \\
-21 \\
-7 \\
15 \\
0 \\
21 \\
49\end{array}$ & $\begin{array}{r}18 \\
-5 \\
-39 \\
\text { N.A. } \\
4 \\
-6 \\
21\end{array}$ & $\begin{array}{r}3 \\
-5 \\
-15 \\
\text { N.A. } \\
-16 \\
3 \\
31\end{array}$ & $\begin{array}{c}\text { Yorkshire } \\
-22 \\
-12 \\
-14 \\
\text { N.A. } \\
20 \\
22 \\
96\end{array}$ & $\begin{array}{r}-11 \\
-10 \\
-12 \\
-86 \\
-15 \\
3 \\
27\end{array}$ & $\begin{array}{r}-31 \\
-88 \\
-26 \\
95 \\
-8 \\
10 \\
109\end{array}$ & $\begin{array}{r}48 \\
31 \\
4 \\
56 \\
-15 \\
8 \\
-3\end{array}$ & $\begin{array}{r}54 \\
41 \\
6 \\
63 \\
-18 \\
11 \\
11\end{array}$ & $\begin{array}{r}23 \\
59 \\
11 \\
55 \\
0 \\
66 \\
38\end{array}$ & $\begin{array}{l}21 \\
44 \\
17 \\
51 \\
-1 \\
55 \\
51\end{array}$ \\
\hline
\end{tabular}


TABLE II-Coefficients of Variation* for the Distribution of Hospital Resources by A.H.A.s in Eight Regions, 1971-2 (Standard Errors of the coefficients of Variation in Parentheses)

\begin{tabular}{|c|c|c|c|c|c|c|c|c|c|c|c|}
\hline & \multicolumn{11}{|c|}{ Provision per Capita } \\
\hline & \multirow[b]{2}{*}{$\begin{array}{c}\text { Current } \\
\text { Expenditure }\end{array}$} & \multicolumn{10}{|c|}{ Beds } \\
\hline & & Total & $\begin{array}{l}\text { General } \\
\text { Medicine }\end{array}$ & $\begin{array}{l}\text { General } \\
\text { Surgery }\end{array}$ & $\begin{array}{c}\text { Traumatic } \\
\text { and } \\
\text { Orthopaedic } \\
\text { Surgery }\end{array}$ & $\begin{array}{l}\text { Mental } \\
\text { Handicap }\end{array}$ & $\begin{array}{l}\text { Mental } \\
\text { Illness }\end{array}$ & Maternity & $\begin{array}{l}\text { Maternity } \\
\text { (Adjusted) }\end{array}$ & $\begin{array}{l}\text { Geriatric } \\
\text { and } \\
\text { Chronic } \\
\text { Sick }\end{array}$ & $\begin{array}{c}\text { Geriatric } \\
\text { and } \\
\text { Chronic Sick } \\
\text { (Adjusted) }\end{array}$ \\
\hline $\begin{array}{l}\text { Overallt coefficient } \\
\text { of variation } \\
\text { Lowest coefficient } \\
\text { of variation } \\
\text { for any region }\end{array}$ & $\begin{array}{l}29 \cdot 2(3 \cdot 5) \\
5 \cdot 6(2 \cdot 0)\end{array}$ & $\begin{array}{c}30 \cdot 1 \\
(3 \cdot 3) \\
5 \cdot 8 \\
(2 \cdot 0)\end{array}$ & $\begin{array}{l}51 \cdot 5 \\
(7 \cdot 2) \\
14 \cdot 1 \\
(5 \cdot 1)\end{array}$ & $\begin{array}{l}35 \cdot 1 \\
(4 \cdot 4) \\
16 \cdot 9 \\
(6 \cdot 1)\end{array}$ & $\begin{array}{c}48 \cdot 7 \\
(1 \cdot 2) \\
32 \cdot 1 \\
(11 \cdot 1)\end{array}$ & $\begin{array}{c}94 \cdot 9 \\
(16 \cdot 0) \\
16 \cdot 0 \\
(5 \cdot 8)\end{array}$ & $\begin{array}{l}69 \cdot 5 \\
(9 \cdot 8) \\
18 \cdot 2 \\
(6 \cdot 7)\end{array}$ & $\begin{array}{c}29 \cdot 9 \\
(3 \cdot 3) \\
12 \cdot 6 \\
(4 \cdot 0)\end{array}$ & $\begin{array}{c}31 \cdot 1 \\
(3 \cdot 7) \\
9 \cdot 8 \\
(3 \cdot 1)\end{array}$ & $\begin{array}{l}32 \cdot 0 \\
(3 \cdot 5) \\
18 \cdot 6 \\
(5 \cdot 1)\end{array}$ & $\begin{array}{l}30 \cdot 5 \\
(3 \cdot 4) \\
16 \cdot 0 \\
(4 \cdot 1)\end{array}$ \\
\hline $\begin{array}{l}\text { Highest coefficient } \\
\text { of variation } \\
\text { for any region }\end{array}$ & $39 \cdot 7(11 \cdot 4)$ & $\begin{array}{c}45 \cdot 1 \\
(11 \cdot 4)\end{array}$ & $\begin{array}{c}51 \cdot 7 \\
(20 \cdot 3)\end{array}$ & $\begin{array}{c}44 \cdot 5 \\
(16 \cdot 6)\end{array}$ & $\begin{array}{c}64 \cdot 4 \\
(18 \cdot 6)\end{array}$ & $\begin{array}{l}121 \cdot 8 \\
(51 \cdot 7)\end{array}$ & $\begin{array}{l}111 \cdot 7 \\
(66 \cdot 0)\end{array}$ & $\begin{array}{c}50 \cdot 2 \\
(19 \cdot 5)\end{array}$ & $\begin{array}{c}52 \cdot 0 \\
(20 \cdot 4)\end{array}$ & $\begin{array}{c}44 \cdot 4 \\
(16 \cdot 6)\end{array}$ & $\begin{array}{c}52 \cdot 5 \\
(26 \cdot 7)\end{array}$ \\
\hline
\end{tabular}

*Calculated from absolute values of per capita provision

+ For all 49 A.H.A.s in our sample or for as many as the data is available (see table I).

boundary patient flows: the balance of patient exports and imports, as it were, for each A.H.A.

Such data could, in fact, be computed using the hospital inpatient statistics ${ }^{13}$ which show the geographical distribution of patient flows. But such information, while interesting, could again be positively misleading. To show that there are currently cross-boundary patient flows is not to demonstrate that these are desirable. In some circumstances, when the hospital facilities in a neighbouring A.H.A. are more accessible because of geographical propinquity or easier lines of communication, this may be a rational response to irrational boundaries. But in other cases, when the flows reflect the lack of local facilities, then the export of patients may reflect a failure to provide appropriately sited and accessible services. In other words, it is essential to distinguish between flows of convenience and flows of necessity, if need be by detailed local studies. If cross-boundary flows reflect difficulty of access within the A.H.A. of residence, this is likely to restrict the use of health services ${ }^{14}$ : an undesirable because an arbitrary form of rationing. They may also impose a considerable financial burden on members of the community because of the travelling costs involved for patients and their relatives. ${ }^{15}$

\section{Findings}

The variation in spending on the hospital services between regions, as already noted, is from $+41 \%$ to $-23 \%{ }^{6}$ The single most important, and unambiguous, conclusion to emerge from table I-which sets out the deviations from the national average in each A.H.A. for expenditure per capita and for various types of hospital beds-is that the range of variations within regions is far greater. For example, in Trent the range for expenditure is from $+34 \%$ to $-62 \%$. The importance of variations in spending between A.H.A.s becomes more pronounced still if the figures for A.H.A.s in different regions are compared: the range then becomes from $+62 \%$ in Liverpool (Mersey) to $-69 \%$ in Sandwell (West Midlands). Teaching areas account for some of the high expenditure figures in the table: these A.H.A.s, it could be argued, fulfil a wider, regional role, and thus require more resources. Interestingly, the region with the least variation between A.H.A.s-Wessex-is also the region where the teaching hospital is a relatively recent creation.

Some of the variations reflect the complementarity between A.H.A.s already discussed. Many patients in Barnsley $(-51 \%)$ and Walsall $(-50 \%)$-both areas with relatively small populations-in fact use the facilities in neighbouring Sheffield and Birmingham. The flow is not, of course, always from the small to the large A.H.A.s: many patients in the eastern part of Birmingham A.H.A. are served by Solihull. The pattern of complementarity is not consistent: for instance, Cornwall $(-30 \%)$ has as its neighbour another below-average A.H.A., Devon $(-14 \%)$.

The evidence is summarized in table II, where we use coefficients of variation to measure the degree of variation in resource provision both between all the A.H.A.s in our sample and within regions. In the latter case, we present only the figures for the regions with the highest and lowest coefficients of variation in each case. Taking expenditure, this shows that while the coefficient of variation (c.v.) for all our A.H.A.s is $29 \cdot 2$, the most homogeneous region has a coefficient of 5.6 as against one of 39.7 for the most variable. (As our analysis is primarily concerned with A.H.A.s as the units of provision, we have purposely not weighted the coefficient by population size.)

\section{BED DISTRIBUTION}

Total expenditure figures may conceal as much as they reveal. They do not tell us anything about how the financial resources are used. It is, therefore, worth looking at the distribution of beds. Unsurprisingly, the figures for the total number of beds by A.H.A. tend to follow the figures for total spending. Once more there are enormous variations: c.v. $=30 \cdot 1$. At one extreme there is Solihull with $74 \%$ more beds than the national average; at the other, there is its West Midlands neighbour, Sandwell, which is $74 \%$ below the national average. But sometimes the figures for expenditure and beds move in opposite directions, so underlining what is a crucial point for the interpretation of the data. This is that expenditure reflects not only the numbers but also the mix of beds: that is, the higher the proportion of "cheap" beds-for example, those in hospitals for the mentally ill (national average 1971-2 weekly cost per patient $£ 25.45$ ) in an A.H.A. the lower will be its total expenditure per head for any given total of beds, while conversely the expenditure will rise the greater the proportion of expensive beds in the acute specialties $(£ 78.58$ a week in regional acute hospitals with more than 100 beds). ${ }^{16}$ Thus, to take two examples from Mersey, Cheshire spends $11 \%$ less than the national average but has $39 \%$ more beds, while Liverpool has $38 \%$ more beds but spends $62 \%$ more than the national average. This is because Cheshire is an example of the concentration of beds for the mentally ill and handicapped in large institutions on the fringe of conurbations. Similar examples include Kingston in the South West Thames and Solihull in the West Midlands.

Inevitably the presence in an A.H.A. of large institutions for the mentally ill or handicapped, serving a much wider population, tends to give a somewhat misleading picture of the distribution of resources. These institutions are due to disappear eventually under current policy and, with them, the distortions they cause. The table therefore provides (wherever available) figures of bed provision for the main acute specialties. Those for general medicine, general surgery, and maternity are particularly interesting, since it can be supposed that A.H.A.s should aim to be reasonably self-sufficient in these basic specialties. In the absence of special local circumstances-for instance, the geographical proximity of facilities in a neighbouring A.H.A., or an extraordinarily healthy population-a shortfall in these specialties would seem to indicate that the local community 
is getting less than average access to health care. In some instances, therefore, the variations for these specialties are even greater than those for the overall figures of expenditure or bed numbers. For example, in general medicine (c.v. $=51.5)$ the range is from $-63 \%$ in Leicestershire and Derbyshire (Trent) to $+192 \%$ in Liverpool. In general surgery (c.v. $=35 \cdot 1$ ) it is from $-45 \%$ in Derbyshire to $+130 \%$ in Liverpool.

\section{POPULATION SPECIFIC SPECIALTIES}

Slightly less dramatic, but still very considerable, variations are apparent in the case of geriatric and chronic sick beds (c.v. $=32.0)$ and maternity beds (c.v. $=29.9)$. These are interesting also in that they are population specific, and it is thus possible to examine the provision of beds in relation to the size of the client groups. The former have been taken to be the over $65 \mathrm{~s}$, since data for the more vulnerable over $75 \mathrm{~s}$ were not consistently available in the profiles; the latter have been defined as women in the 15-44 age bracket. In the case of the geriatric and chronic sick beds, the effects of such an adjustment is sometimes to increase the disparities. It emphasizes the deficiency of such beds, in terms of the population at risk, in West Sussex and the Wirrall for instance, though in other A.H.A.s-with a less elderly population-the effect is in a reverse direction, as in Buckinghamshire and Doncaster. Even more interesting, possibly, are the adjusted figures for maternity. Not only is it national policy to move towards having all births in hospital, which would suggest homogeneity in the provision of beds in terms of the relevant population, but on social grounds it could also be argued that ease of access is particularly important, and that therefore each A.H.A. should be reasonably self-sufficient. In practice, though, the variations are remarkably high-and are certainly not smoothed out with any consistency by adjusting for the relevant population. The figures also hint that there may be differences in regional policy-for example, variations for maternity beds in the South West are much less than variations for any of the other acute specialties.

The number of beds available is, of course, only an imperfect, proxy measure of the health care provided. To quote the latest report of the Hospital Advisory Service, "A large number of beds does not necessarily mean an active or effective service... It is clear that the success of a department depends less on the number of beds than on the way the beds are used."17 But in the absence of better measures it is still the best way of assessing the distribution of scarce resources, since manpower can rarely be related to specialty by A.H.A.

\section{Policy Implications}

There are two conclusions which must not be drawn from our data, whatever the temptations. Firstly, no firm conclusion should be reached about any particular A.H.A.'s level of provision: the data, because of the nature of the area profiles, allow questions to be asked but do not guarantee sufficiently accurate information about any individual authority. Secondly, it cannot automatically be assumed that any A.H.A. which has resources below the national average should get more. The national average is a sliding one: the number of beds per capita has continued to fall in line with D.H.S.S. policy, which is to reduce them even further. Thus A.H.A.s with a below-average provision may simply be a few years ahead of those with an above-average level of resources. Similarly, the criteria for deciding an appropriate level of provision are far from selfevident: formulas, whether based on equal spending per head of population or equal spending per particular at risk groups of the population, can be criticized on the grounds of ignoring local circumstances or morbidity patterns.

But, all this said, the main implication of the data survives both reservations about its accuracy and uncertainty about the criteria for allocating resources: variations in provision between
A.H.As are so gross that a number of conclusions for policy making follow inescapably.

The most self-evident of these is that any attempt to achieve greater equity by levelling up the most deprived A.H.A.s would be very expensive, since they fall so far below the national average. The cost of such a levelling-up process can be computed in terms of current expenditure, and indeed the exercise has been carried out in the Oxford region where it has been calculated that it would cost just over $£ 5 \mathrm{~m}$. per year (an increase of about $10 \%$ on the 1971-2 regional budget) "to bring all areas up to the level of the best for each service."18 In addition to such increases in current spending, greater equity would require a heavy investment of capital which, in present circumstances, does not seem a realistic short-term policy option.

\section{ROBIN HOOD POLICY}

Some of the grosser variations could no doubt be eliminated by up-grading the non-capital elements in the worst-off A.H.A.s, which means in effect compensating for having few beds by making those that are available more intensively staffed and so increasing the patient through-put. This points to two policy options. The first would be to redistribute resources away from the richest A.H.A.s to the poorest. Such a Robin Hood policy could produce fairly quick results, but the frictional costsin terms of local opposition and resistance by the staff-would be high. It might also mean less efficient utilization of existing resources. The second option would be to ensure that any extra funds that become available are steered to the worst-off A.H.A.s while the rest stand still. Such selective incrementalism would, however, take a very long time to show results at a time when very few extra resources in real terms, after allowing for inflation, are being made available to the N.H.S. and public services in general. In either case, though, there is one clear implication: that a policy of redistributing resources to the regions is inadequate unless there is also an effective policy for redistributing them within the regions.

To say that there should be such a policy is, of course, to beg the question of what the objectives should be in distributing resources to the A.H.A.s. To what extent should it be the aim of policy to make A.H.A.s self-sufficient, at least so far as a "basic package" of the main acute specialties are concerned? And to what extent can those A.H.A.s which are heavily dependent on the services of a neighbouring authority-either because of the lack of resources or because the "natural" flow of patients is across the boundary-be expected to offer a comprehensive service?

This last point leads to a still wider consideration. One of the main criticisms of reorganization has been that it has created too many administrative tiers: the D.H.S.S., the regions, the areas, and the districts. Our data suggests that, in many instances, the A.H.A. may be dispensable. Why have such an authority if its boundaries do not make sense in terms of the distribution of health care resources but are the by-product, as it were, of local government reorganization whose logic (if any) is not necessarily the logic of health care provision? The other side of this particular coin is that, for the foreseeable future, handing over control of the A.H.A.s to the local authoritieswhether directly, or as the result of changes in their membership-would not seem a realistic policy option. While most local authorities are self-sufficient, whatever the level of the services they provide, the same is not true of many A.H.A.s.

We thank Mrs. Naomi Connelly, for her help in extracting the data from the profiles.

\section{References}

1 Bowen, H. R., and Jeffers, J. R., The Economics of Health Services. New York, General Learning Press, 1972. 
2 Field, M. G., Systèmes de prestations de soins prioritaires dans les pays de l'est: le cas de l'union sovietique, paper given at the Fourth International Conference of Social Science and Medicine, Elsinore, Denmark, August 1974.

3 Ministère de la Santé Publique, Santé et Securité Sociale: Tableaux, 1972. Paris, La Documentation Francaise, 1973.

4 Germany (Federal Republic), Der Bundesminister für Jugend, Familie und Gesundheit, Gesundheitsbericht. Bonn, G.F.P., 1971

5 Butler, J. R., in collaboration with Bevan, J. M., and Taylor, R. C., Family Doctors and Public Policy. London, Routledge and Kegan Paul, 1973.

- Noyce, J.,Snaith, A. H., and Trickey, A. J., 1974 Lancet, 1, 554. British Medical Association, 1970.

${ }^{8}$ Logan, R. F. L., et al., Dynamics of Medical Care, Memoir No. 14. London, London School of Hygiene and Tropical Medicine, 1972.

- Department of Health and Social Security, Circular 3/70 to Regional Hospital Board Chairmen, 1970.

10 West, P. A., Allocation and Equity in the Public Sector: the Hospital Revenue
Allocation Formula, Institute of Social and Economic Research, University of York, reprint series, No. 155.

11 Secretary of State for Social Services, National Health Service Reorganization: England, Cmnd. 5055. London H.M.S.O., 1972.

12 Department of Health and Social Security, Preparation of Area Profile, Schedule to H.R.C. (72)7

13 Department of Health and Social Security and Office of Population Censuses and Surveys, Report on Hospital In-patient Enquiry for the year 1971. London, H.M.S.O., 1973.

14 Acton, J. P., Demand for Health Care when Time Prices Vary more than Money prices, The New York Rand Institute, May 1974.

15 Gruer, Rosamund, Outpatient Services in the Scottish Border Counties, Scottish Home and Health Department. Edinburgh, H.M.S.O., 1972, 16 Department of Health and Social Security, Hospital Costing Returns for the Year ended 31 st March 1972. London H.M.S.O., 1973.

17 Department of Health and Social Security, Annual Report of the Hospital Advisory Service for the Year 1973. London, H.M.S.O., 1974.

18 Rickard, J. H., The Allocation of Revenue Expenditure between Areas in the Reorganized Health Service, Oxford Regional Health Authority, 1974.

\section{Joint Consultants Committee}

The foint Consultants Committee met on 21 fanuary at the Royal College of Surgeons of England, with Mr. Alan Parks in the chair.

\section{Membership Changes}

The Chairman weloomed back $\mathrm{Mr}$. A. H. Grabham after his recent illness and reported changes in the Committee's membership. Dr. M. M. Burrows had been appointed to fill the vacancy caused by the appointment of Dr. C. E. Astley as one of the vice-chairmen, and Dr. Cyril Scurr had been appointed to replace Professor J. G. Robson on his appointment as a Vicechairman. The Chairman further reported that Mr. O. J. A. Gilmore had replaced Dr. R. B. Hopkinson as the junior representative, that Professor Sir Fergusson Anderson had replaced Sir Andrew Kay, and that $\mathbf{M r}$. W. Drummond and Dr. E. M. McIlrath had replaced Dr. A. W. Wright and Dr. J. H. D. Miller.

\section{Assessment Scheme for Overseas Doctors}

The main item discussed by the Committee was the assessment scheme for overseas doctors (published in the B.M.f., 7 December 1974, p. 606). Sir John Richardson, President of the General Medical Council, attended the meeting for the discussion.

The Committee's view was that doctors from overseas should be required to pass a written examination followed by a clinical examination to the level of the British qualification. It saw the attachment scheme as a period of adaptation and not a test of a man's ability. Furthermore, the J.C.C. objected to the recognition for full registration under reciprocity of qualifications when the G.M.C. was not allowed to inspect in the country of origin.

Sir JOHN RICHARDSON made it clear that the G.M.C. had not the power to compel anybody to take its test who under present law had the right to full registration under reciprocity, but it was hoped that new legislation would alter that situation.

It had been argued strongly that doctors should be assessed overseas, he continued, but the Government would not help in arranging the assessment and was not prepared to put pressure on overseas countries to facilitate the tests. Furthermore, India and Ceylon had now refused to allow the Educational Council for Foreign Medical Graduates' examination to be taken in their countries.

The G.M.C. had asked the non-university examining bodies if they could set up a test, said Sir John. The G.M.C. wanted a language test that was meaningful and the type of knowledge test that would embrace the clinical side as opposed to the academic. It had also asked that the test should not be one given at the time of qualification and before preregistration year but should be suitable for a man who would fill S.H.O. posts. Two of three bodies consulted had advised that they could not manage to have a clinical examination. The Scottish Triple Qualification Board was confident that by using peripheral hospitals it could organize a clinical examination. The Conjoint Board and the Apothecaries were adamant that they could not. After a long discussion, it had been agreed that a test could be established which it was hoped would be superior to the E.C.F.M.G., and that it should be linked with an improved clinical attachment scheme. The test would evaluate the candidate's ability to comprethend and to express himself in English, both spoken and written, as well as his professional knowledge.

\section{TEMPORARY REGISTRATION}

If a man wished to be temporarily registered, Sir John continued, he would sit the test, and perhaps the result might be: "As this man is so good and his English is so clear it would be a waste of time to attach him, and we recommend the G.M.C. to register him temporarily." The G.M.C. would, of course, use its own discretion in the matter. It would also receive notifications that a doctor's English was so bad or his knowledge inadequate (or both) that there would be no point without further instruction for that man to be attached.

Many doctors would fall in the middle and the G.M.C. and the candidate would both be informed that in the opinion of the Temporary Registration Assessment Board the candidate could go for an attachment. The assessment would have to be for at least two weeks before the man could look for a job. At the end of that time the G.M.C. would ask for a detailed report (for which it would pay a fee) and inquire whether other people had been involved in the assessment. Participation in the assessment scheme itself-and the Department had agreed to this-would also attract an honorarium.
Sir John said that the G.M.C was sure that it had prepared a better clinical assessment scheme than the E.C.F.M.G. would offer. It could be argued that it was desirable to have a clinical examination but he still could not believe that a properly conducted attachment scheme should be inferior to any clinical examination.

The G.M.C. hoped to start the scheme in June and proper notice had to be given to those who would do the testing. An embarrassing situation could arise if there were great delays for reasons beyond the G.M.C.'s control. He hoped that the J.C.C. would suppont the improved attachment scheme. If that were not possible in time the G.M.C. thought that the present scheme was better than nothing.

\section{Doctors Seeking Entry}

Dr. CYRIL SCURR pointed out that apprehensions had been expressed not only about temporary assessment but also about automatic registration of certain foreign medical graduates. He recalled that he had been a member of the first working parties set up to study the feasibility of the temporary registration assessment, and at that time, he had argued that foreign doctors wishing to work in Britain should pass the M.R.C.S., L.R.C.P., the Scottish triple qualification, or the L.S.A.

It had been claimed that about 10000 such doctors were currently seeking admission to the U.K. and that 3000 were to be "processed" in the next 12 months. Of those, 1500 holding Indian and similar qualifications would be exempted from assessment and entitled to automatic registration by the G.M.C.

At another national committee it had been represented recently that the G.M.C. did not visit, as regularly as it might, overseas medical schools whose degrees it recognized for practice in the U.K. In Dr. Scurr's view those policies were wrong. The G.M.C could not in honour recognize qualifications when it could not inspect. Inspections here showed that there were many overseas doctors who were registrars of five to eight years' standing who rarely, if ever, sat higher examinations. They were merely using what were regarded as training posts as a permanent job offering them a higher standard of living than they could 